\title{
Design of two-dimensional perovskite solar cells with superior efficiency and stability
}

\section{Diseño de celdas solares de perovskitas bidimensionales con eficiencia y estabilidad mejorada}

\author{
Daniel Ramírez (iD ${ }^{1 *}$ Franklin Jaramillo \\ ${ }^{1}$ Centro de Investigación, Innovación y Desarrollo de Materiales CIDEMAT, Universidad de Antioquia Calle 70 \# 52-21. C. \\ P. 050010. Medellín, Colombia.
}

\author{
CITE THIS ARTICLE AS: \\ D. Ramírez and F. Jaramillo. \\ "Design of two-dimensional \\ perovskite solar cells with \\ superior efficiency and \\ stability", Revista Facultad de \\ Ingeniería Universidad de \\ Antioquia, no. 100, pp. 67-74, \\ Jul-Sep 2021. [Online]. \\ Available: https : \\ //www.doi.org/10.17533/ \\ udea.redin. 20210424
}

\section{ARTICLE INFO:}

Received: November 11, 2020 Accepted: April 12, 2021

Available online: April 14, 2021

\section{KEYWORDS:}

Two-dimensional metal halide perovskites; solar cells; stability; organic cations

Perovskitas de haluro metal bidimiensionales; celdas solares; estabilidad; cationes orgánicos

\begin{abstract}
Pervskite solar cells have attracted extensive attention from researchers worldwide due to their rapid development and efficiency. Nevertheless, stability is still an issue that limits the advance of this technology. In this work, we present the fabrication and characterization of two-dimensional perovskites of the Ruddlesden-Popper's family $(A)_{2}(M A)_{n-1} P b n l_{3 n+1}$ (three different $A$-site large cations were investigated: $A=n$-propylammonium, t-Butylammonium or Benzylammonium). The modulation of the large organic cations increased the band gap of the materials and improved moisture and thermal stability, making it possible to fabricate PSCs. Even though the organic interlayers intrinsically reduce the transport properties of the devices and therefore lower currents are obtained in the layered systems, a remarkable efficiency of $10.35 \%$ was obtained for $\left.(B \cup A)_{2}(M A)_{2} \mathrm{~Pb}_{3}\right|_{10}$, with superior stability, and therefore, it was possible to retain $68 \%$ of its initial value after $1700 \mathrm{~h}$ for devices without encapsulation.
\end{abstract}

RESUMEN: Las celdas solares de Perovskita han atraído la atención de la comunidad científica en los últimos años debido a los avances significativos en su eficiencia. Sin embargo, su estabilidad es todavía un problema que limita el avance de esta tecnología. En este trabajo se presenta la fabricación y caracterización de pervoskitas bidimiensionales pertenecientes a la familia Ruddlesden-Poppery $(A)_{2}(M A)_{n-1} P b n l_{3 n+1}$ Ise estudiaron 3 cationes grandes en la posición A: $n$-propilamonio, t-Butilamonio o Bencilamonio). La modulación de estos cationes que promueven la formación de una estructura bidimensional, generó un incremento en el bandgap de los materiales, así como una mejora en su estabilidad térmica y a la humedad. Aunque naturalmente la introducción de estos cationes genera una disminución en las propiedades de transporte, reduciendo la corriente de los dispositivos, se lograron obtener dispositivos con eficiencias de $10,35 \%$ para $\left.(B \cup A)_{2}(M A)_{2} \mathrm{~Pb}_{3}\right|_{10}$, que, presentando una estabilidad mejorada, lograron retener el $68 \%$ de valor inicial luego de $1700 \mathrm{~h}$ sin encapsulamiento.

\section{Introduction}

The recent emergence of hybrid perovskite materials with the general formula $\mathrm{AMX}_{3}\left(\mathrm{~A}=\mathrm{Cs}^{+}, \mathrm{CH}_{3} \mathrm{NH}_{3}{ }^{+}\right.$, or $\mathrm{HC}\left(\mathrm{NH}_{2}\right)_{2}{ }^{+}$; $\mathrm{M}=\mathrm{Pb}_{2}{ }^{+}$; and $\mathrm{X}=\mathrm{Cl}^{-}, \mathrm{Br}^{-}$, and $\mathrm{I}^{-}$) has attracted the attention of numerous academics within the photovoltaic field in recent years, since the first report of Kojima et al.[1] in 2009. The three-dimensional (3D) methylammonium (MA)

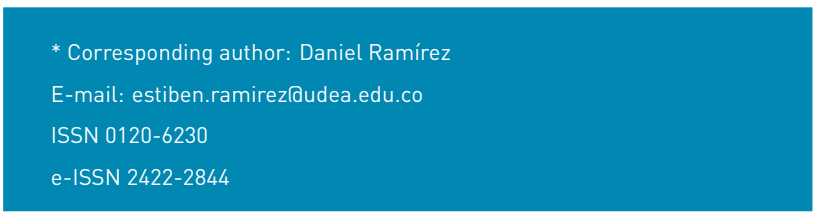

lead iodide $\left(\mathrm{MAPbl}_{3}\right)$ is the most promising material to achieve solar cell devices with high performance [2-5]. The main advantages of this material are related to its exceptional properties as an adequate solar cell absorber, including small exciton binding energy [6], high extinction coefficient [7], adequate band gap [8], and long exciton and charge diffusion lengths [9].

Nevertheless, there are two main drawbacks in the future development of lead-based perovskite devices: the degradation of the material by atmospheric moisture [10] and the toxicity of the resulting lead [11]. Improving the moisture stability of the material can also help to reduce the impact of lead toxicity because it could prevent the 
water-soluble perovskite from easily dissolve. Replacing MA with formamidium (FA) has resulted in better thermal stability, but not in better moisture stability $[12,13]$. Nevertheless, there is a broad range of less water-soluble organic cations that can be used to replace MA. But, these larger cations exceed Goldschmit's tolerance factor that determines the formation of 3D perovskites $[14,15]$. However, two-dimensional (2D) stable perovskite structures are also easy to obtain. Among these 2D stable perovskites are the Ruddlesden-Popper layered perovskites with the general formula $A_{2} B_{n-1} P_{n} I_{3 n+1}$, which can go from simple $2 D(n=0)$ to $3 D(n=\infty)$.

Cao et al. [16] investigated the 2D Ruddlesden-Popper $\left.(B A)_{2}(M A)_{n-1} P_{n}\right|_{3 n+1}$ layered perovskite where BA corresponded to the n-butylammonium cation $\mathrm{CH}_{3}\left(\mathrm{CH}_{2}\right)_{3} \mathrm{NH}_{3}{ }^{+}$. They found improved moisture stability for the best photovoltaic device with an efficiency of $4.02 \%$ when $n=3$. Later, in the same system, Tsai et al. [17] Carried out a hot casting method to achieve a better orientation of the films, which allowed them to increase from $4.44 \%$ to $11.44 \%$. Similar 2D Ruddlesden-Popper systems were also investigated using phenylethylammonium cation, $\mathrm{PhC}_{2} \mathrm{H}_{5} \mathrm{NH}_{3}{ }^{+}$(PEA) in the $(\mathrm{PEA})_{2}(\mathrm{MA})_{2} \mathrm{~Pb}_{3} \mathrm{I}_{10}$ system; the resulting devices showed improved moisture stability and efficiencies ranging from $4.73 \%$ to $7.02 \%$ that highly depended on the scan rate (indicating hysteresis) [18].

It is important to notice that there is still a lot of work to develop regarding the layered perovskite structure considering the options in terms of the value of $n$ and the multiple organic cations combination [19]. The previous works concluded that the most promising system for 2D Ruddlesden-Popper layered perovskite is obtained when $n=3$ [20]. These results should be taken as an initial point to keep improving the stability and performance of these new layered systems in order to contribute to the faster development of lead hybrid perovskite solar cells. The right choice of the organic cation in these systems determines the final properties of the active layer since large cations with lower polarity can improve the moisture stability but can also affect the transport properties across the organic chains. Therefore, in this work, we investigate and report the fabrication and properties of $3 D$ $\mathrm{MAPbl}_{3}$ and 2D Ruddlesden-Popper layered perovskites with $n=3$. Three organic cations of different nature, such as n-propylammonium (PA), t-butylammonium (BUA) and benzylammonium (BEA) were selected to obtain the three-layered perovskites $\left.(P A)_{2}(M A)_{2} P_{3}\right|_{10}$, $(B U A)_{2}(M A)_{2} \mathrm{~Pb}_{3} \mathrm{I}_{10}$ and $(\mathrm{BEA})_{2}(\mathrm{MA})_{2} \mathrm{~Pb}_{3} \mathrm{I}_{10}$. Due to differences in hydrophobicity, size and structure, all materials showed very dissimilar photovoltaic properties, but in all cases improved moisture stability compared to the 3D $\mathrm{MAPbl}_{3}$ perovskite. Different from PA and
BEA, the shorter branched BUA cation allowed adequate moisture tolerance and better transport properties for the $\left.(B U A)_{2}(M A)_{2} P_{3}\right|_{10}$ system.

\section{Experimental methods}

\subsection{Perovskite synthesis}

Methylammonium iodide (MA), Propylammonium iodide (PA), t-Butylammonium iodide (BUA), and Benzylammonium iodide (BEA) from Dyesol were used as organic cations. Dimethyl sulfoxide (DMSO, Sigma Aldrich) and dimethylformamide (DMF, Alfa Aesar) were used as solvents, and lead iodide (Alfa Aesar) as a lead source. In order to obtain the $\mathrm{MAPbl}_{3}$ precursor solution, MA and lead iodide were dissolved and DMSO 11:1:1 molar ratio; $55 \%$ wt.) in N,N-dimethylformamide (DMF, Alfa Aesar) and stirred at room temperature for $1 \mathrm{~h}$. The precursor solution of the layered perovskites was obtained in a similar way. The concentration was kept constant, and the molar ratio was MA: PA, BUA or BEA: lead iodide (2:2:3). The films were obtained by spin-coating procedure on the precursor solutions on top of a glass substrate at 3500 rpm for $25 \mathrm{~s}$ under air atmosphere. During spinning, 500 $\mu \mathrm{L}$ of Diethyleter (Aldrich) were dropped on the substrate after 10 seconds. The films were then annealed at $65^{\circ} \mathrm{C}$ for $1 \mathrm{~min}$ plus $100^{\circ} \mathrm{C}$ for $10 \mathrm{~min}$.

\subsection{Device fabrication}

Devices were fabricated on ITO-coated glass (Naranjo). The substrates were washed with neutral soap (Inmunodet neutro-neutral detergent) and sequentially sonicated in DI water, acetone, and isopropanol. Then, they were treated with ultraviolet ozone for $5 \mathrm{~min}$. The $\mathrm{NiO}_{\mathrm{x}}$ hole transporting layer was fabricated by spin-coating a $\mathrm{NiO}_{x}$ dispersion [21] at $3000 \mathrm{rpm}$ for $30 \mathrm{~s}$ with a $3 \mathrm{~s}$ ramp under air atmosphere. All the perovskite layers were then deposited by spin-coating the precursor solution at $3500 \mathrm{rpm}$ for 25 s. During spinning, $500 \mu \mathrm{L}$ of Diethyleter (Aldrich) were dropped on the substrate after 10 seconds. The films were then annealed at 65 oC for 1 min plus 100 oC for $10 \mathrm{~min}$. PCBM (1-Material) was deposited via spin-coating a 20 $\mathrm{mg} / \mathrm{mL}$ solution in chlorobenzene (CB) at $2000 \mathrm{rpm}$ for 30 s. Rodhamine 101 was deposited on top of the PCBM layer by spin coating a $0.5 \mathrm{mg} / \mathrm{L}$ solution at $4000 \mathrm{rpm}$ for $30 \mathrm{~s}$. Finally, to complete the devices, $100 \mathrm{~nm}$ silver electrodes were thermally evaporated under vacuum ( $\approx 10-6$ mbar) at a deposition rate around $\approx 0.1 \mathrm{~nm} \mathrm{~s}^{-1}$ resulting in devices with an active area of $0.09 \mathrm{~cm}^{2}$.

\subsection{Characterization}

X-ray diffractograms were collected from $2 \theta=5^{\circ}$ to $50^{\circ}$ in a Bragg-Brentano geometry, from the prepared thin films 
a)

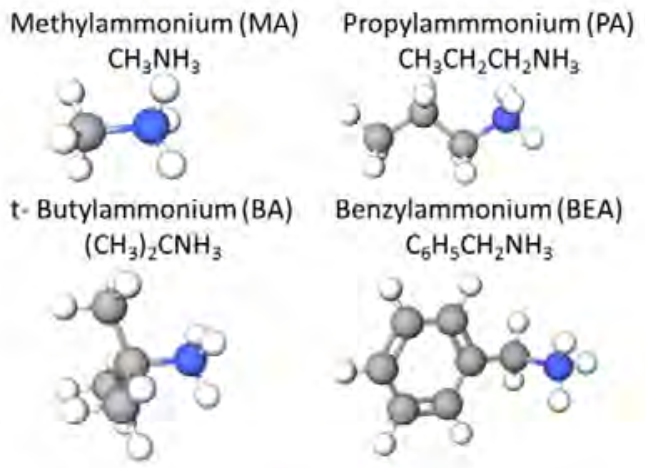

c)

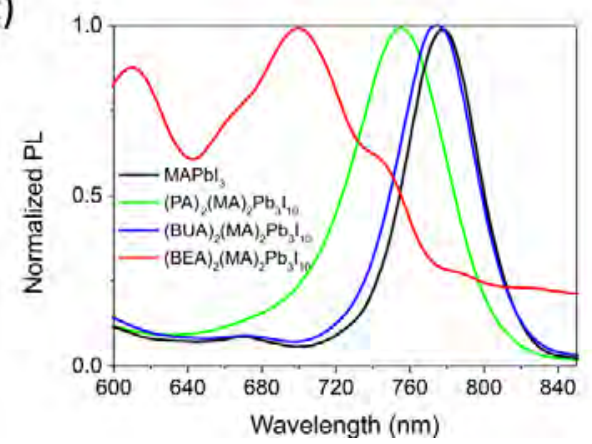

b)

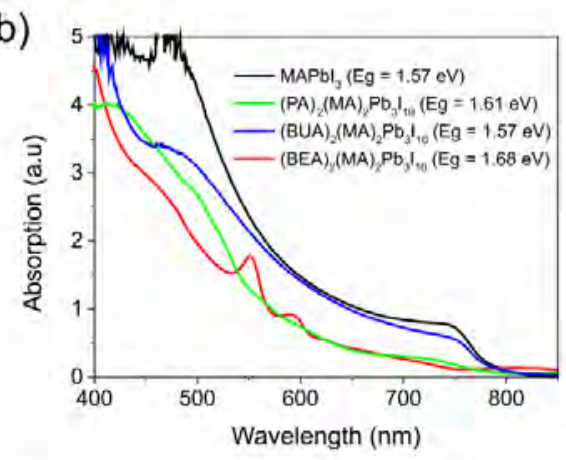

d)

\section{Contact Angle}
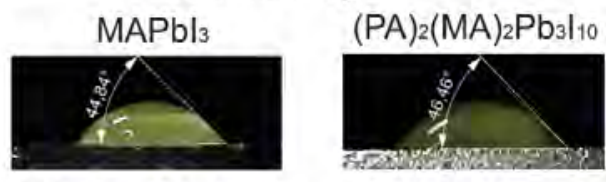

$(\mathrm{BUA})_{2}(\mathrm{MA})_{2} \mathrm{~Pb}_{3} \mathrm{I}_{10}$

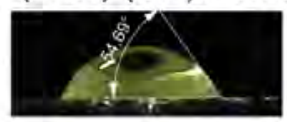

Figure 1 Two-dimensional perovskites. a) Structure of the different organic cations used to synthesize the layered perovskites. b) Absorption spectra and c) PL intensity for the thin films of layered perovskites. d) Photograph of contact angle of water drop indicating superior hydrophobicity for the layered perovskites

in a PANalytical diffractometer, using $\mathrm{Cu} \mathrm{K} \theta(1.5408 \AA)$ radiation with a step size of $0.04^{\circ}$ and a speed of $2^{\circ}$ per minute. Optical absorption and Photoluminescence were measured in the range of $400-850 \mathrm{~nm}$ using a Cary 100 and a Cary Eclipse Agilent spectrometer, respectively. The electrical characterization of the devices was performed using a 4200SCS Keithley system at a voltage swept speed around $400 \mathrm{mV} / \mathrm{s}$ in combination with an Oriel sol3A sun simulator, which was calibrated to AM1.5G standard conditions using an oriel $91150 \mathrm{~V}$ reference cell. An Oriel IQE 200 was used to determine the external quantum efficiency in the range of 300 to $800 \mathrm{~nm}$. Morphology images were obtained by AFM in a MFP-3D infinity from Oxford Instruments. Photoconductive AFM images were also obtained in the same equipment, but the samples were connected to an external bias between the ITO substrate and the AFM tip. Then, a voltage sweep was performed, and the current passing to the tip was measured; for dark measurements the samples were not illuminated, while for the samples were illuminated with a white LED.

\section{Results}

The structure of the different organic cations used to obtain the hybrid perovskites is shown in Figure 1a. It is important to notice $n$-propylammonium (PA) is a linear chain based on three carbon atoms, t-butylammonium (BUA) is a branched-chain based on four carbon atoms, and Benzylammonium (BEA) is an aromatic cation with one carbon atom and an aromatic phenyl group. Due to the increased content of carbon atoms in relation to Methylammonium (MA), the introduction of these cations makes it possible to obtain more hydrophobic structures. Nevertheless, according to the tolerance factor [22], large cations do not allow obtaining 3D perovskite. The calculated absorption onset increased with a tendency similar to size of the organic cation, resulting in $1.57 \mathrm{eV}$ for $\mathrm{MAPb}_{3}, 1.61 \mathrm{eV}$ for $(\mathrm{PA})_{2}(\mathrm{MA})_{2} \mathrm{~Pb}_{3} \mathrm{I}_{10}, 1.57 \mathrm{eV}$ for $(\mathrm{BUA})_{2}(\mathrm{MA})_{2} \mathrm{~Pb}_{3} \mathrm{I}_{10}$ and $1.68 \mathrm{eV}$ for $(\mathrm{BEA})_{2}(\mathrm{MA})_{2} \mathrm{~Pb}_{3} \mathrm{I}_{10}$ (Figure $1 \mathrm{~b}$ ) in concordance with the PL emission as shown in Figure 1c. The optical band gaps (Eg) in the layered materials increased with respect to the $3 \mathrm{D}$ perovskite because of quantum confinement effects [23]. These results are similar to other reports for hybrid perovskites where the $\left.(B A)_{2}(M A)_{n-1} P b_{n}\right|_{3 n+1}$ series increase with the decreased thickness of the inorganic slabs from $n=\infty$ to $n=1$ [16]. However, in all cases, the band gap shift is not very marked due to the presence of layer-edge-states (LES), indicating that the excitons are almost ionized into free carriers at room temperature, giving a pathway for dissociating excitons into longer-lived free-carriers [24]. The efficient PL observed in all samples is a highly required property for photovoltaic applications because 
it is an indication of carrier generation, thus allowing access to the highest possible open-circuit voltage. [25] Note that the largest BEA cation showed three different emission peaks, in agreement with the exciton absorption in the $500 \mathrm{~nm}$ to $550 \mathrm{~nm}$ range. On the other hand, the change of the film's hydrophobicity was also monitored. As observed in Figure 1d, the contact angle for a droplet of water $(\sim 7 \mu \mathrm{L})$ increased as the size of the organic cation increased, ranging from $44.84^{\circ}$ for $\mathrm{MAPbl}_{3}$ to $60.51^{\circ}$ for $(\mathrm{BEA})_{2}(\mathrm{MA})_{2} \mathrm{~Pb}_{3} \mathrm{I}_{10}$. This improvement in the contact angle should also be reflected in improved moisture resistance.

The structure of the obtained materials was corroborated by X-ray diffraction (XRD). As shown in Figure 2, the 3D structure of the $\mathrm{MAPbl}_{3}$ perovskite was modified, and hybrid layered perovskites were obtained, as confirmed by the appearance of the new peaks at low diffraction angles. The layered materials corresponded to $\left.(\mathrm{PA})_{2}(\mathrm{MA})_{2} \mathrm{~Pb}_{3}\right|_{10}$, $(\mathrm{BUA})_{2}(\mathrm{MA})_{2} \mathrm{~Pb}_{3} \mathrm{I}_{10}$, and $(\mathrm{BEA})_{2}(\mathrm{MA})_{2} \mathrm{~Pb}_{3} \mathrm{I}_{10}$, a product of slicing the $3 \mathrm{D}$ perovskite into well-defined $2 \mathrm{D}$ slabs.

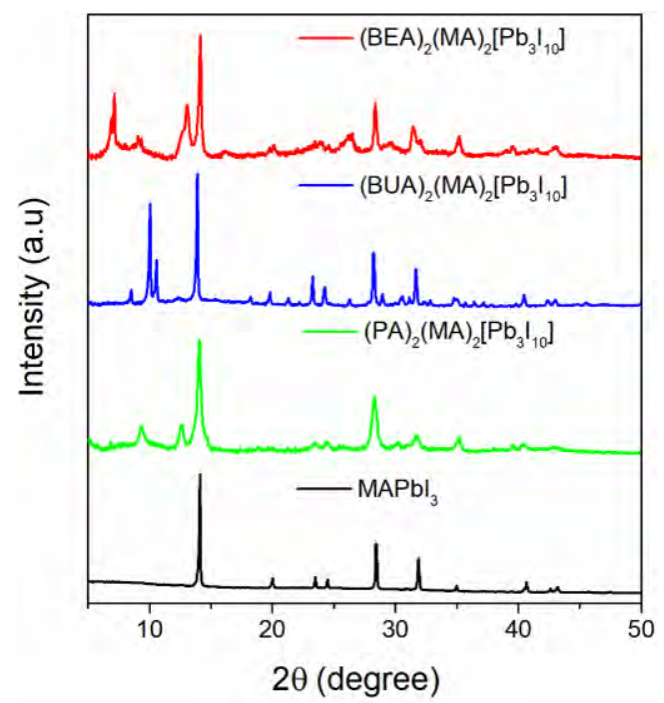

Figure 2 Experimental XRD spectra for three-dimensional perovskite $\left(\mathrm{MAPb}_{3}\right)$ and the two-dimensional perovskites

In order to explore the stability in the layered materials, the films were exposed to a moisture stability test at $\sim 80 \%$ Relative Humidity. Figure 3a shows the evolution of the films up to $27 \mathrm{~h}$ exposition time. $\mathrm{MAPbl}_{3}$ sample showed very evident degradation, and after $19 \mathrm{~h}$, translucent yellowish zones were formed, indicating perovskite hydration [26]. On the other hand, the layered samples only started to show some important change in color after $27 \mathrm{~h}$, and therefore, they were more stable, as shown in Figure 3b. The stability trend followed the previous indications in which more stable films are obtained when a larger cation is introduced.

Temperature stability is also an important aspect for photovoltaic applications since it was previously demonstrated that organic cations such as formamidinium (FA) can improve the thermal stability of the perovskite $[27,28]$. Therefore, the films were also exposed to a temperature stability test at $85^{\circ} \mathrm{C}$ for 15 days. Like the moisture test, the layered perovskites presented improved thermal stability compared to the 3D MA-based perovskite, probably due to the more difficult volatilization of the large organic cations compared to the MA.
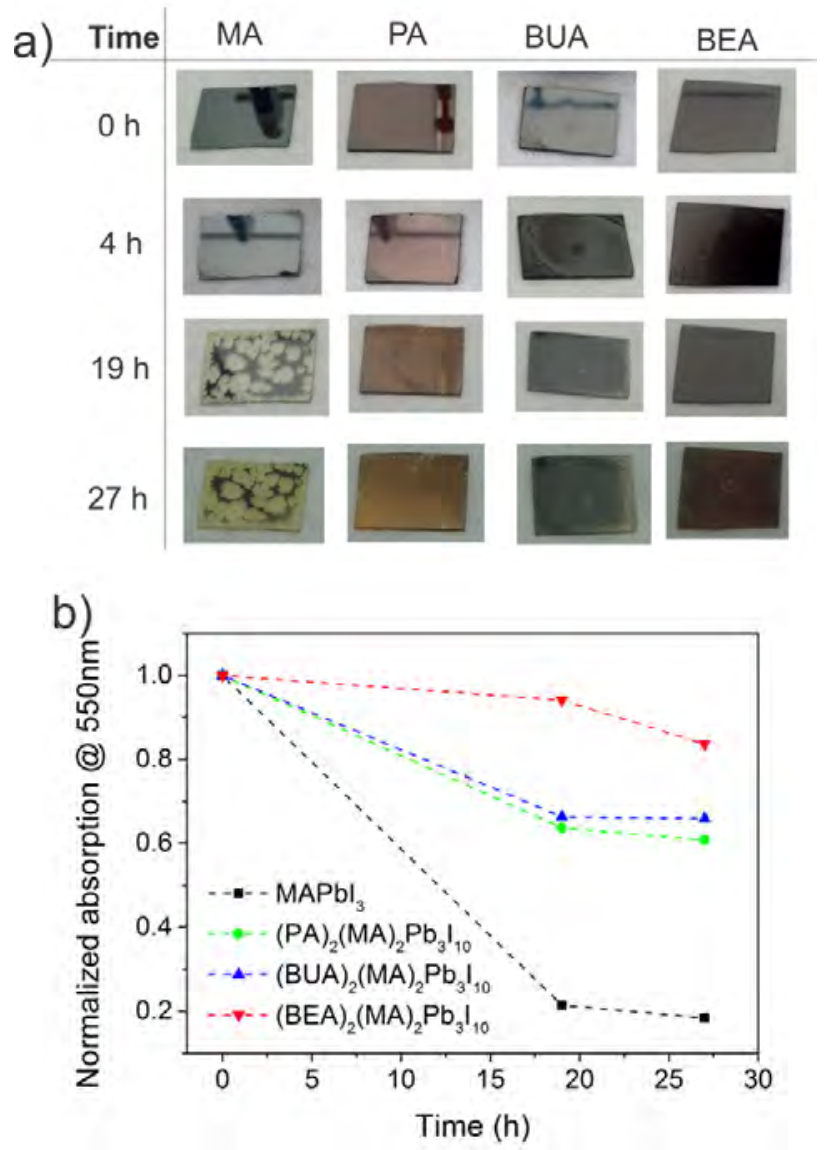

Figure 3 Improved moisture stability of 2D perovskites. a) Images of the films and $\mathbf{b}$ ) Absorption decay as a function of time for the moisture stability test at $80 \%$ R.H

The introduction of the large inorganic cations in the 2D perovskites had an impact on the morphology of the materials, as observed in Figure 4a. $\mathrm{MAPbl}_{3}$ sample showed a common morphology composed of well-defined grains with an average size of $180 \mathrm{~nm}$. For the $\left.(P A)_{2}(M A)_{2} \mathrm{~Pb}_{3}\right|_{10}$ perovskite with two additional linearly connected carbons, the morphology presented less defined grains embedded in what seems to be an amorphous phase. This phase should correspond to small grains limited in size by the PA layer, which confirms that the layered structure does not have a large-range $3 \mathrm{D}$ continuous order. On the other hand, for the case 
a)

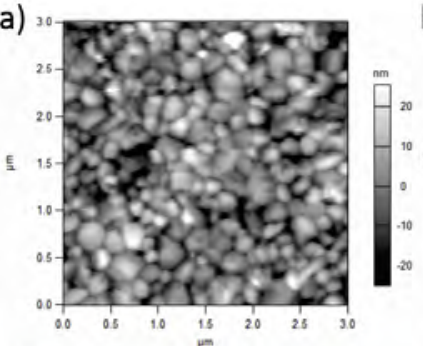

e)

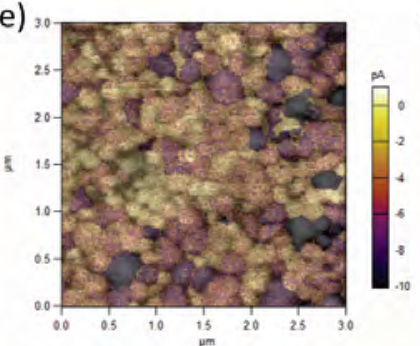

b)

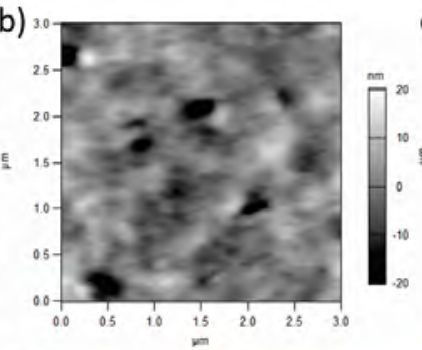

f) 3

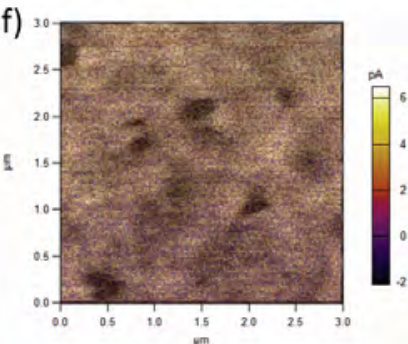

c) 30

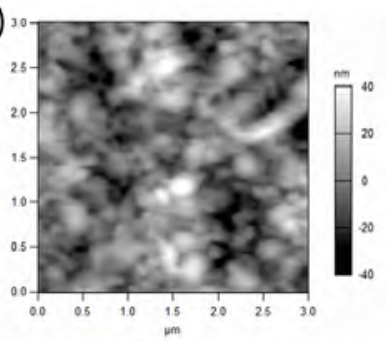

g)

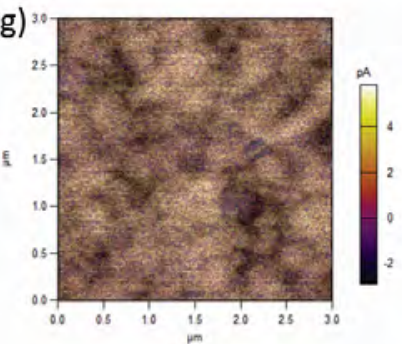

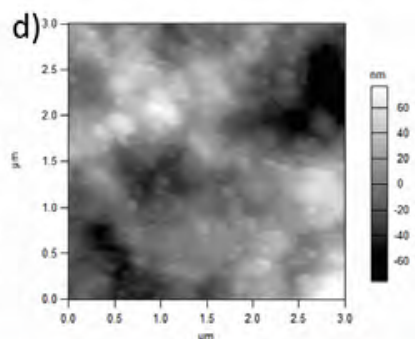

h)

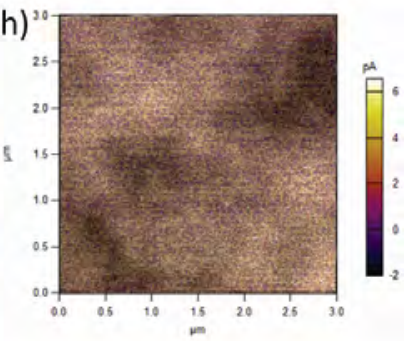

Figure 4 Morphology and electrical properties of layered perovskites. a-d) AFM images showing the morphology of MAPbI , $(\mathrm{PA})_{2}(\mathrm{MA})_{2} \mathrm{~Pb}_{3} \mathrm{I}_{10},(\mathrm{BUA})_{2}(\mathrm{MA})_{2} \mathrm{~Pb}_{3} \mathrm{I}_{10}$, and for $(\mathrm{BEA})_{2}(\mathrm{MA})_{2} \mathrm{~Pb}_{3} \mathrm{I}_{10}$ films, respectively. e-h) superposed AFM and photoconductive AFM images of $\mathrm{MAPb}_{3},\left.(\mathrm{PA})_{2}(\mathrm{MA})_{2} \mathrm{~Pb}_{3}\right|_{10}$, (BUA $)\left._{2}(\mathrm{MA})_{2} \mathrm{~Pb}_{3}\right|_{10}$, and for $(\mathrm{BEA})_{2}(\mathrm{MA})_{2} \mathrm{~Pb}_{3} \mathrm{I}_{10}$ films, respectively

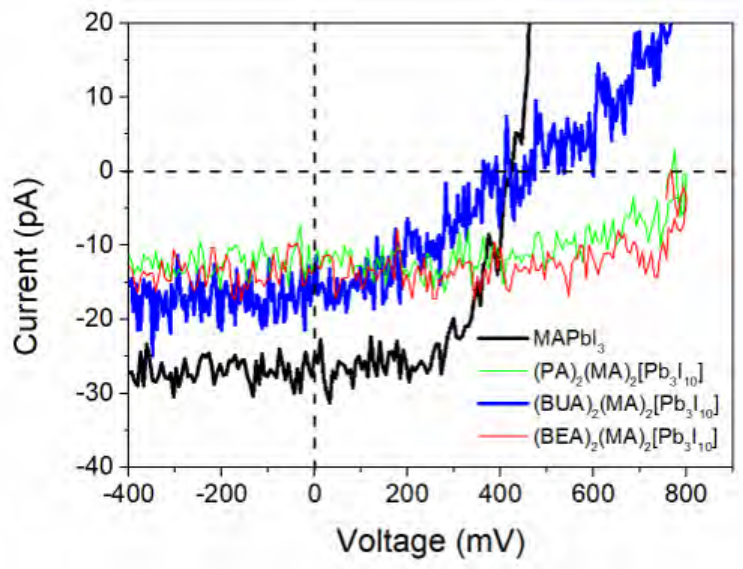

Figure $5 \mathrm{~J}-\mathrm{V}$ curve of perovskite films obtained from photoconductive AFM

of the BUA cation with three extra carbon atoms in the $\left.(B \cup A)_{2}(M A)_{2} \mathrm{~Pb}_{3}\right|_{10}$ structure, large grains could be obtained, probably because this branched cation only results in a continuous chain of 2 carbon atoms, making the separation of the layers shorter than for the PA cation, as previously discussed in terms of its smaller unit cell. The phenyl group in the BEA cation is the largest group in the layered perovskites; it allowed the formation of small grains that are smaller than the ones formed by BUA, but larger than those formed by PA cations, probably because of a better interaction between the phenyl groups. This difference in morphology is very important since the transport properties of these materials are remarkably influenced by the phase continuity [29]. Consequently, it would be ideal to have improved moisture and temperature resistance, with less affected transport properties.

In order to study both, photoactive and transport properties of the films, photoconductive AFM was performed. The films were illuminated while a voltage sweep between $-400 \mathrm{mV}$ and $800 \mathrm{mV}$ was applied. This allowed obtaining a J-V curve that served to compare the photovoltaic properties of the films, as indicated in Figure 5. The generated current followed the decreasing order, 3D $\mathrm{MAPbl}_{3}>$ BUA- >BEA-> PA-based 2D perovskites, but the Voc increased in the opposite way because of the larger band gaps of the layered perovskites. The photoconductive AFM images were superposed to the morphology images, as shown in Figure 4e-4h. 3D MAPbl${ }_{3}$ presented a well-defined contrast between the produced current and each individual grain, similar to reports that suggested transport dependence upon material's facets [30]. The $\left.(B \cup A)_{2}(M A)_{2} \mathrm{~Pb}_{3}\right|_{10}$ sample was the only layered perovskite that produced some contrast between grains, indicating the closer behavior to a 3D perovskite.

The high quality and uniformity of the layered perovskite films encouraged the fabrication of planar photovoltaic devices. Solar cells fabricated with these films yielded interesting results compared to the $3 \mathrm{D}$ perovskite. Table 1 summarizes the photovoltaic performance of the fabricated devices. The reference device for the $\mathrm{MAPbl}_{3}$ sample resulted in an average power conversion efficiency of $15.02 \%$, with a best performing device of $16.16 \%$. $(\mathrm{PA})_{2}(\mathrm{MA})_{2} \mathrm{~Pb}_{3} \mathrm{I}_{10}$ and $(\mathrm{BEA})_{2}(\mathrm{MA})_{2} \mathrm{~Pb}_{3} \mathrm{I}_{10}$ devices presented 

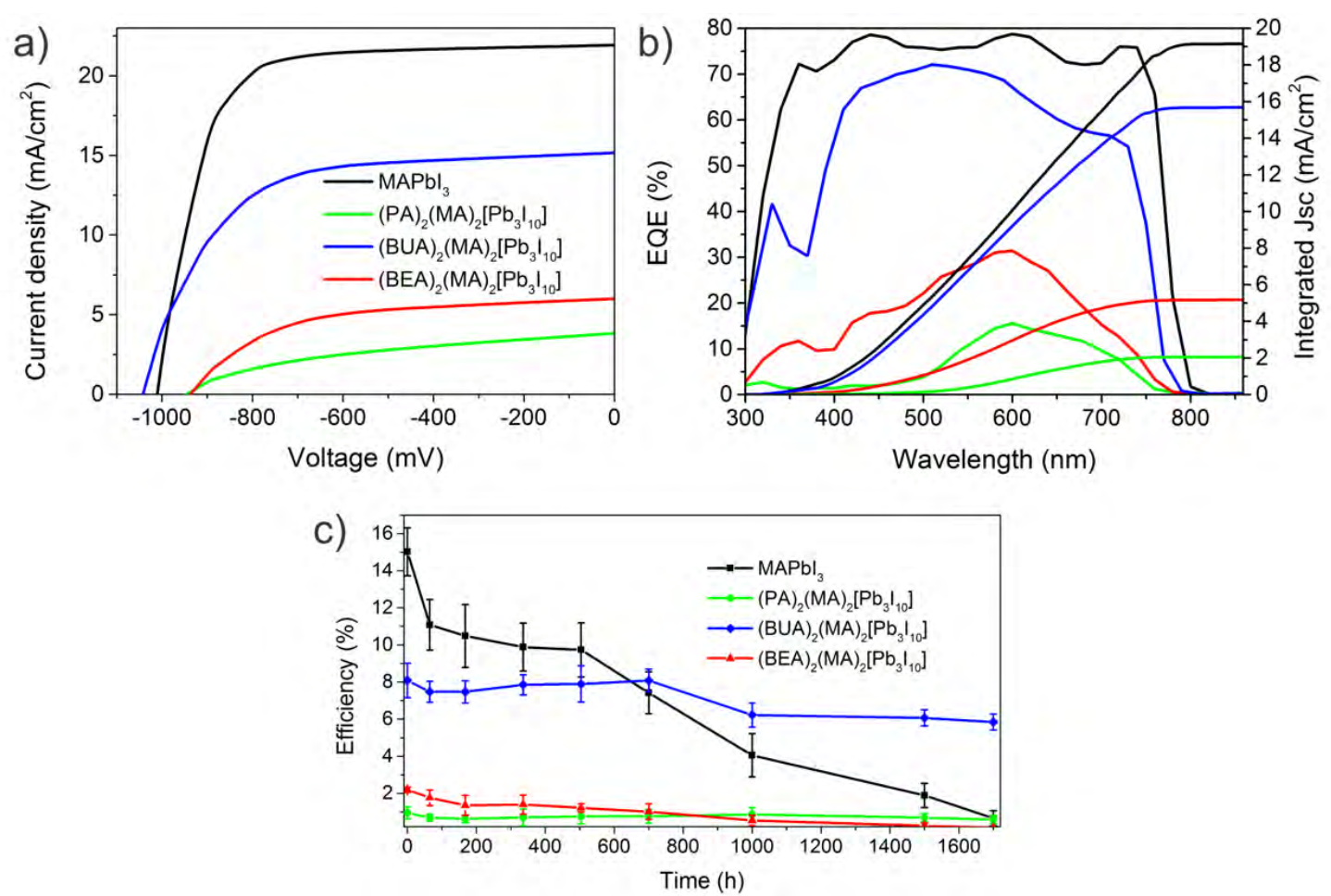

Figure 6 Photovoltaic performance of layered perovskites. a) Representative J-V curves, b) EQE spectra, and c) stability test at $60 \%$ R.H up to $1700 \mathrm{~h}$ for perovskite devices without encapsulation

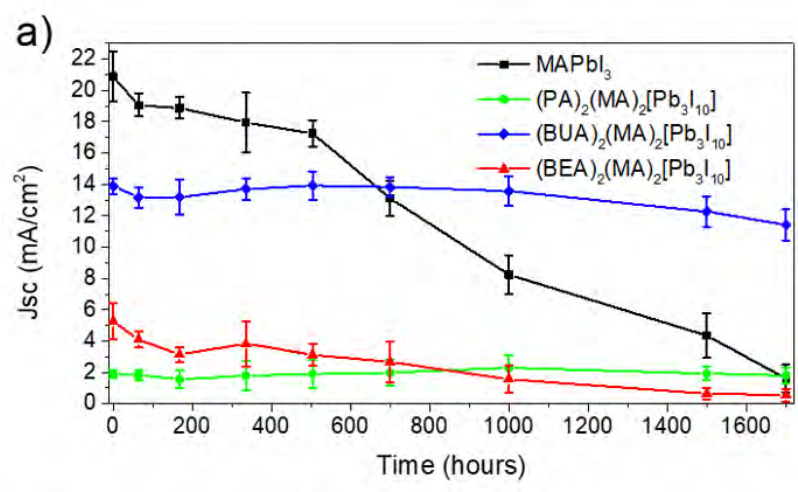

b)
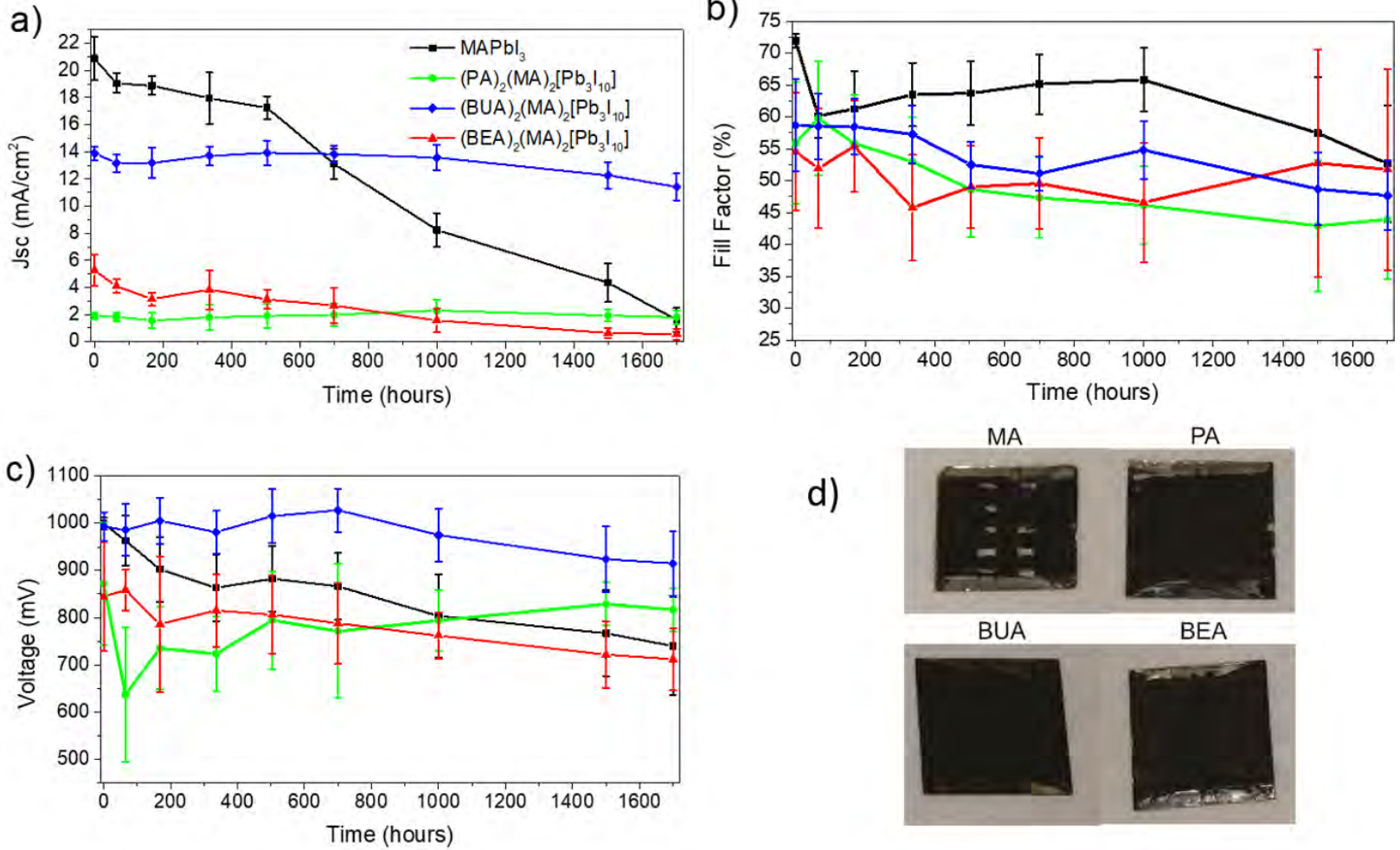

d)

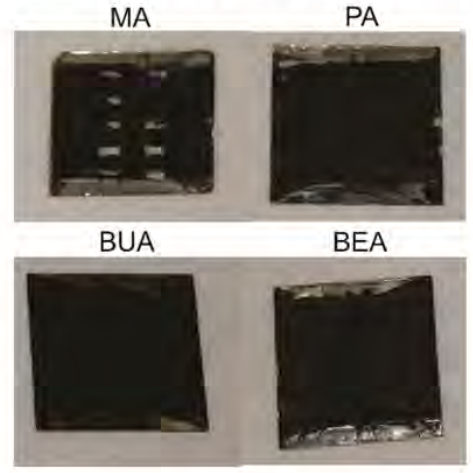

Figure 7 Stability test at $60 \%$ R.H up to 1700 h for perovskite devices without encapsulation. al Current Density, b) Fill Factor, and c) Voltage. d) Image of the devices after $1000 \mathrm{~h}$ 
Table 1 Summarized photovoltaic parameters of the fabricated devices. Note: values in parenthesis correspond to the parameters of the best-obtained devices

\begin{tabular}{|c|c|c|c|c|c|c|}
\hline Perovskite & $\begin{array}{l}\text { Jsc } \\
\left(\mathrm{mA} / \mathrm{cm}^{2}\right)\end{array}$ & $\begin{array}{l}\text { Voc } \\
\text { (mV) }\end{array}$ & $\begin{array}{l}\text { Fill Factor } \\
(\%)\end{array}$ & $\begin{array}{l}\text { PCE } \\
(\%)\end{array}$ & $\begin{array}{l}\text { Rs } \\
\left(\Omega . \mathrm{cm}^{2}\right)\end{array}$ & $\begin{array}{l}\text { Rsh } \\
\left(\text { (n.cm }{ }^{2}\right)\end{array}$ \\
\hline $\mathrm{MAPbl}_{3}$ & $\begin{array}{l}20.87 \pm 1.57 \\
(21.92)\end{array}$ & $\begin{array}{l}1011 \pm 12 \\
(1018)\end{array}$ & $\begin{array}{l}71.91 \pm 1.11 \\
(72.37)\end{array}$ & $\begin{array}{l}15.02 \pm 1.29 \\
(16.16)\end{array}$ & $\begin{array}{l}8.99 \pm 2.03 \\
(7.16)\end{array}$ & $\begin{array}{l}976 \pm 335 \\
(1225)\end{array}$ \\
\hline$(\mathrm{PA})_{2}(\mathrm{MA})_{2} \mathrm{~Pb}_{3} \mathrm{l}_{10}$ & $\begin{array}{l}1.99 \pm 0.48 \\
(2.68)\end{array}$ & $\begin{array}{l}872 \pm 130 \\
(794)\end{array}$ & $\begin{array}{l}55.89 \pm 9.53 \\
(51.63)\end{array}$ & $\begin{array}{l}0.95 \pm 0.33 \\
(1.10)\end{array}$ & $\begin{array}{l}48.96 \pm 27.86 \\
(18.27)\end{array}$ & $\begin{array}{l}1967 \pm 1343 \\
(2116)\end{array}$ \\
\hline$(\mathrm{BUA})_{2}(\mathrm{MA})_{2} \mathrm{~Pb}_{3} \mathrm{I}_{10}$ & $\begin{array}{l}13.70 \pm 1.51 \\
(15.14)\end{array}$ & $\begin{array}{l}1026 \pm 26 \\
(1044)\end{array}$ & $\begin{array}{l}59.72 \pm 2.99 \\
(65.50)\end{array}$ & $\begin{array}{l}8.25 \pm 1.14 \\
(10.35)\end{array}$ & $\begin{array}{l}13.85 \pm 3.33 \\
(12.80)\end{array}$ & $\begin{array}{l}711 \pm 422 \\
(461)\end{array}$ \\
\hline$(\mathrm{BEA})_{2}(\mathrm{MA})_{2} \mathrm{~Pb}_{3} \mathrm{l}_{10}$ & $\begin{array}{l}5.25 \pm 1.15 \\
(4.94)\end{array}$ & $\begin{array}{l}844 \pm 115 \\
(922)\end{array}$ & $\begin{array}{l}54.57 \pm 9.17 \\
(56.58)\end{array}$ & $\begin{array}{l}2.19 \pm 0.34 \\
(2.57)\end{array}$ & $\begin{array}{l}28.25 \pm 13.21 \\
(23.12)\end{array}$ & $\begin{array}{l}953 \pm 279 \\
(763)\end{array}$ \\
\hline
\end{tabular}

an average efficiency of $1.10 \%$ and $2.19 \%$, respectively. This low performance was mainly determined by the low obtained current. This is an expected result since the relatively poor efficiency in layered systems is due to the inhibition of out-of-plane charge transport by the organic cations, which acts as an insulating spacing layer between the inorganic conduction slabs, and therefore, one approximation to the best results relies on the possibility to have films with a preferential out-of-plane alignment with respect to the contacts to facilitate efficient charge transport [17]. The improved current for the $(\mathrm{BUA})_{2}(\mathrm{MA})_{2} \mathrm{~Pb}_{3} \mathrm{I}_{10}$ layered perovskite material led to better photovoltaic performance, reaching a $10.35 \%$ best and an $8.25 \%$ average efficiency, respectively.

Figure 6a shows the representative J-V curves for all the obtained devices. The EQE shown in Figure $6 \mathrm{~b}$ corroborated the obtained current, which presented a similar tendency as in the photoconductive AFM in the order, 3D $\mathrm{MAPbl}_{3}>\mathrm{BUA}->\mathrm{BEA}->\mathrm{PA}$-based 2D perovskites. On the other hand, comparative long-term stability measurements for all perovskites were performed in devices without encapsulation exposed to $60 \%$ R.H. The efficiency evolution for this test is shown in Figure 6c. A faster decay was observed for the 3D perovskite, resulting in almost null efficiency after $1700 \mathrm{~h}$, while the $(\mathrm{PA})_{2}(\mathrm{MA})_{2} \mathrm{~Pb}_{3} \mathrm{I}_{10}$ and $(\mathrm{BEA})_{2}(\mathrm{MA})_{2} \mathrm{~Pb}_{3} \mathrm{I}_{10}$ perovskites showed a slower decay, but due to the low performance, this improved stability did not represent any advantage. On the contrary, $(\mathrm{BUA})_{2}(\mathrm{MA})_{2} \mathrm{~Pb}_{3} \mathrm{l}_{10}$ retained $68 \%$ of its initial value, resulting in devices with an average efficiency of $5.98 \%$ after $1700 \mathrm{~h}$.

The main factor affecting the efficiency decay was $J_{s c}$ degradation, as observed in Figure $7 \mathrm{a}-7 \mathrm{c}$ for $\mathrm{J}_{\mathrm{sc}}, \mathrm{V}_{\mathrm{oc}}$, and FF decay. The $\mathrm{MAPbl}_{3}$ devices started to become transparent (Figure 7d), suggesting that the most probable degradation mechanism was perovskite hydration [26], which was less evident for the two-dimensional samples.

\section{Conclusions}

We have deeply studied different hybrid perovskite materials based on the Ruddlesden-Popper's family. Structural characterization and device performance demonstrated that the right selection of the organic cations plays an important role in the final perovskite morphology and properties since the three large organic cations used to fabricate the layered perovskites showed improved moisture and thermal stability but marked differences in the photovoltaic performance. Additionally, an efficiency of $10.35 \%$ for the devices with $\left.(B \cup A)_{2}(M A)_{2} P_{3}\right|_{10}$ used as the active layer was obtained. These unencapsulated devices retained $68 \%$ of their performance when exposed to $60 \%$ R.H during $1700 \mathrm{~h}$, which is superior to the control $\mathrm{MAPbl}_{3}$ devices. Our results indicate that the proper selection of the organic spacer in a two-dimensional perovskite is crucial for achieving better stability of PSCs.

\section{Declaration of competing interest}

We declare that we have no significant competing interests including financial or non-financial, professional, or personal interests interfering with the full and objective presentation of the work described in this manuscript.

\section{Acknowledgement}

The authors acknowledge the financial support of the Colombia Scientific Program within the framework of the call Ecosistema Cientifíco (Contract FP44842-218-2018).

\section{References}

[1] A. Kojima, K. Teshima, Y. Shirai, and T. Miyasaka, "Organometal halide perovskites as visible-light sensitizers for photovoltaic cells," Journal of the American Chemical Society, vol. 131, no. 17, Apr. 14, 2009. [Online]. Available: https://doi.org/10.1021/ja809598r 
[2] X. Li and et al., "A vacuum flash-assisted solution process for high-efficiency large-area perovskite solar cells," Science, vol. 353, no. 6294, Jul. 01, 2016. [Online]. Available: https: //doi.org/10.1126/science.aaf8060

[3] M. Park, J. S. Park, I. K. Hanb, and J. Y. Oh, “High-performance flexible and air-stable perovskite solar cells with a large active area based on poly(3-hexylthiophene) nanofibrils," Journal of Materials Chemistry A, vol. 4, no. 29, Jun. 23, 2016. [Online]. Available: https://doi.org/10.1126/science.aaf8060

[4] M. M. Lee1, J. Teuscher1, T. Miyasaka, T. N. Murakami, and H. J. Snaith, "Efficient hybrid solar cells based on meso-superstructured organometal halide perovskites," Science, vol. 338, no. 6107, Nov. 02 2012. [Online]. Available: https://doi.org/10.1126/science.1228604

[5] W. Chen and et al., "Hybrid interfacial layer leads to solid performance improvement of inverted perovskite solar cells," Energy \& Environmental Science, vol. 8, no. 2, Dec. 03, 2014. [Online]. Available: https://doi.org/10.1039/C4EE02833C

[6] C. S. Jiang and et al., "Carrier separation and transport in perovskite solar cells studied by nanometre-scale profiling of electrical potential," Nature Communications, vol. 6, no. 8397, Sep. 28, 2015. [Online]. Available: https://doi.org/10.1038/ncomms 9397

[7] H. S. Jung and N. G. Park, "Perovskite solar cells: From materials to devices," Small, vol. 11, no. 1, Jan. 07, 2015. [Online]. Available: https://doi.org/10.1002/smll.201402767

[8] T. Baikie and et al., "Synthesis and crystal chemistry of the hybrid perovskite $\left(\mathrm{ch}_{3} \mathrm{nh}_{3}\right) \mathrm{pbi}_{3}$ for solid-state sensitised solar cell applications," Journal of Materials Chemistry A, vol. 1, no. 18, Mar. 12, 2013. [Online]. Available: https://doi.org/10.1039/C3TA10518K

[9] S. D. Stranks and et al., "Electron-hole diffusion lengths exceeding 1 micrometer in an organometal trihalide perovskite absorber," Science, vol. 342, no. 6156, Oct. 18, 2013. [Online]. Available: https://doi.org/10.1126/science.1243982

[10] S. Guarnera and et al., "Improving the long-term stability of perovskite solar cells with a porous $\mathrm{al}_{2} \mathrm{O}_{3}$ buffer layer," The Journal of Physical Chemistry Letters, vol. 6, no. 3, Jan. 13, 2015. [Online]. Available: https://doi.org/10.1021/jz502703p

[11] K. Wang, Z. Liang, X. Wang, and X. Cui, "Lead replacement in $\mathrm{ch}_{3} \mathrm{nh}_{3} \mathrm{pbi}_{3}$ perovskites," Advanced Electronic Materials, vol. 1 no. 10, Aug. 22, 2015. [Online]. Available: https://doi.org/10.1002/ aelm.201500089

[12] G. E. Eperon and et al., "Formamidinium lead trihalide: a broadly tunable perovskite for efficient planar heterojunction solar cells," Energy \& Environmental Science, vol. 7, no. 3, Jan. 06, 2014. [Online]. Available: https://doi.org/10.1039/C3EE43822H

[13] G. Gordillo, O. Virgüez, C. Otálora, C. Calderón, and C. Quiñones, "Synthesis and optimization of properties of thin films of $\mathrm{fa}_{\mathrm{x}}\left(\mathrm{ma}_{1-\mathrm{x}}\right) \mathrm{pbi}_{3}$ grown by spin coating with perovskite structure to be used as active layer in hybrid solar cells," Revista UIS Ingenierías, vol. 19, no. 1, Nov. 27, 2010. [Online]. Available: https://doi.org/10.18273/revuin.v19n1-2020008

[14] V. M. Goldschmidt, "Die gesetze der krystallochemie," Naturwissenschaften, vol. 14, May. 1926. [Online]. Available: https://doi.org/10.1007/BF01507527

[15] T. J. Jacobsson, M. Pazoki, A. Hagfeldt, and T. Edvinsson, “Goldschmidt's rules and strontium replacement in lead halogen perovskite solar cells: Theory and preliminary experiments on $\mathrm{Ch}_{3} \mathrm{nh}_{3} \mathrm{sri}_{3}$," The Journal of Physical Chemistry C, vol. 119, no. 46, Oct. 26, 2015. [Online]. Available: https://doi.org/10.1021/acs.jpcc. 5 b06436

[16] D. H. Cao, C. C. Stoumpos, O. K. Farha, J. T. Hupp, and M. G. Kanatzidis, "2d homologous perovskites as light-absorbing materials for solar cell applications," Journal of the American Chemical Society, vol. 137, no. 24, May. 28, 2015. [Online]. Available: https://doi.org/10.1021/jacs.5b03796

[17] H. Tsai and et al., "High-efficiency two-dimensional ruddlesden-popper perovskite solar cells," Nature, vol. 536, Jul. 06, 2016. [Online]. Available: https://doi.org/10.1038/nature18306

[18] I. C. Smith, E. T. Hoke, D. Solis, M. D. McGehee, and H. I. Karunadasa, "A layered hybrid perovskite solar cell absorber with enhanced moisture stability," Angewandte, vol. 126, no. 42, 0ct. 13, 2014. [Online]. Available: https://doi.org/10.1002/ange.201406466

[19] D. Ramírez and et al., "Layered mixed tin-lead hybrid perovskite solar cells with high stability," ACS Energy Letters, vol. 3, no. 9, Aug. 25, 2018. [Online]. Available: https://doi.org/10.1021/acsenergylett. $8 b 01411$

[20] Y. Dong, D. Lu, Z. Xu, H. Lai, and Y. Liu, "2-thiopheneformamidinium-based $2 \mathrm{~d}$ ruddlesden-popper perovskite solar cells with efficiency of $16.72 \%$ and negligible hysteresis," Advanced Energy Materials, vol. 10, no. 28, Jun. 05, 2020. [Online]. Available: https://doi.org/10.1002/aenm.202000694

[21] J. Ciro and et al., "Self-functionalization behind a solution-processed nio film used as hole transporting layer for efficient perovskite solar cells," ACS Applied Materials \& Interfaces, vol. 9, no. 14, Mar. 28 , 2017. [Online]. Available: https://doi.org/10.1021/acsami.6b15975

[22] G. Kieslich, S. Sun, and A. K. Cheetham, "An extended tolerance factor approach for organic-inorganic perovskites," Chemical Science, vol. 6, Apr. 14, 2015. [Online]. Available: https://doi.org/10.1039/C5SC00961H

[23] R. L. Milot and et al., "Charge-carrier dynamics in 2d hybrid metal-halide perovskites," Nano Letters, vol. 16, no. 11, Sep. 30, 2016. [Online]. Available: https://doi.org/10.1021/acs.nanolett. 6b03114

[24] J. C. Blancon and et al., "Extremely efficient internal exciton dissociation through edge states in layered 2d perovskites," Science, vol. 355, no. 6331, Mar. 24, 2017. [Online]. Available: https://doi.org/10.1126/science.aal4211

[25] 0. D. Miller, E. Yablonovitch, and S. R. Kurtz, "Strong internal and external luminescence as solar cells approach the shockley-queisser limit," IEEE Journal of Photovoltaics, vol. 2, no. 3, Jun. 06, 2012. [Online]. Available: https: //doi.org/10.1109/JPHOTOV.2012.2198434

[26] A. M. A. Leguy, "Reversible hydration of $\mathrm{ch}_{3} \mathrm{nh}_{3} \mathrm{pbi}_{3}$ in films, single crystals, and solar cells," Chemistry and Materials, vol. 27, no. 9, Apr. 05, 2015. [Online]. Available: https://doi.org/10.1021/acs. chemmater.5b00660

[27] J. W. Lee, D. J. Seol, A. N. Cho, and N. G. Park, "High-efficiency perovskite solar cells based on the black polymorph of hc $\left(\mathrm{nh}_{2}\right)_{2} \mathrm{pbi}_{3}, "$ Advanced Materials, vol. 26, no. 29, Aug. 06, 2014. [Online]. Available: https://doi.org/10.1002/adma.201401137

[28] J. W. Lee and et al., "Formamidinium and cesium hybridization for photo and moisture stable perovskite solar cell," Advanced Energy Materials, vol. 5, no. 20, Oct. 21, 2015. [Online]. Available: https://doi.org/10.1002/aenm.201501310

[29] S. Chen and G. Shi, "Two dimensional materials for halide perovskite based optoelectronic devices," Advanced Materials, vol. 29, no. 24 , Mar. 03, 2017. [Online]. Available: https://doi.org/10.1002/adma. 201605448

[30] G. E. Eperon and D. S. Ginger, "Perovskite solar cells: Different facets of performance," Nature Energy, vol. 1, no. 16109, Jul. 04, 2016. [Online]. Available: https://doi.org/10.1038/nenergy.2016.109 